\title{
A New Formalist approach to narrative Christology: Returning to the structure of the Synoptic Gospels
}

\begin{abstract}
Author:
Michal Beth Dinkler ${ }^{1,2}$

\section{Affiliations:}

${ }^{1}$ Yale University School of

Divinity, United States

${ }^{2}$ Department of New Testament Studies, Faculty of Theology, University of Pretoria, South Africa

Research Project Registration Project Leader: A.G. van Aarde(1)

Research Project no.: 2334682

Description:

Prof. Dr Michal Beth Dinkler is participating in the research project, 'Biblical Theology and Hermeneutics', directed by Prof. Dr Andries van Aarde, Post Retirement Professor in the Dean's Office at the Faculty of Theology of the University of Pretoria.
\end{abstract}

\section{Corresponding author:}

Michal Beth Dinkler,

mb.dinkler@yale.edu

Dates:

Received: 29 Aug. 2017 Accepted: 05 Sept. 2017

Published: 31 Oct. 2017

How to cite this article: Dinkler, M.B., 2017, 'A New Formalist approach to narrative Christology: Returning to the structure of the Synoptic Gospels', HTS Teologiese Studies/ Theological Studies 73(1), a4801. https://doi.org/ 10.4102/hts.v73i1.4801

\section{Copyright:}

C 2017. The Authors. Licensee: AOSIS. This work is licensed under the Creative Commons Attribution License.

\section{Read online:}

$\begin{array}{ll}\square & \begin{array}{l}\text { Scan this QR } \\ \text { code with your } \\ \text { smart phone or } \\ \text { mobile device } \\ \text { to read online. }\end{array}\end{array}$

Today, scholars employ the label 'narrative Christology' with relative frequency, though they mean different things when they do so. In this article, I argue that to date, narrative Christology has not yet fully explored the parameters of what it means to attend closely to the narrative form of the Gospels' presentations of Jesus. I propose, further, that recent developments in literary theory's so-called 'New Formalism' offer useful tools and concepts for moving in that direction. The first part of the article briefly outlines previous scholarship, identifying similarities and differences between various approaches labelled 'narrative Christology'. The second section introduces the major concepts of New Formalism and how they might extend narrative Christology's capacity to take narrative form seriously as an object of analysis. The third section of the article offers a case study of a passage that appears in the triple tradition the intercalated healing stories of Jairus' daughter and the haemorrhaging woman in Mark 5.21-43; Luke 8.40-56; and Matthew 9.18-26 - in order to explore narrative structure on the micro-level. My ultimate goal is to show how New Formalism can contribute to a more robust narrative Christology and, in so doing, advance our understanding of the distinctive ways in which the Synoptic Gospels construct the figure of Jesus.

\section{Introduction}

In 1979, Robert Tannehill published a groundbreaking article introducing the concept of 'narrative christology', which he defines as an approach that 'tak[es] seriously the narrative form ... in discussing th[e] Gospel's presentation of Jesus Christ' (Tannehill 1979:57). ${ }^{1}$ In the 1980s, narrative Christology developed beyond Tannehill's reading of Mark's Gospel to interpretations of the other canonical Gospels as their own unique forms of narrative Christology. Today, scholars continue to employ the label 'narrative Christology' with relative frequency, though they mean different things when they do so. In this article, I shall argue that to date, narrative Christology has not yet fully explored the parameters of what it means to attend closely to the narrative form of the Gospels' presentations of Jesus. I propose, further, that recent developments in literary theory's so-called 'New Formalism' offer useful tools and concepts for moving in that direction. ${ }^{2}$

The first part of my article briefly outlines previous scholarship, identifying similarities and differences between various approaches labelled 'narrative Christology'. The second section introduces the major concepts of New Formalism and how they might extend narrative Christology's capacity to take narrative form seriously as an object of analysis. The third section of the article offers a case study of a passage that appears in the triple tradition - the intercalated healing stories of Jairus' daughter and the haemorrhaging woman in Mark 5.21-43; Luke 8.40-56; and Matthew 9.18-26 in order to explore narrative structure on the micro-level. ${ }^{3}$ My ultimate goal is to show how New Formalism can contribute to a more robust narrative Christology and, in so doing, advance our understanding of the distinctive ways in which the Synoptic Gospels construct the figure of Jesus.

\section{Narrative Christology: A brief overview}

Christology in the Synoptic Gospels was a topic of scholarly discussion long before Tannehill's 1979 article introducing 'narrative Christology'. Questions related to the various Gospels' 1.Tannehill's article concerns the Gospel of Mark, but scholars have since read the other canonical Gospels through the same lens.

2.This theoretical discussion ought to be distinguished from the late 20th-century movement among poets that is also called 'New Formalism' (on which, see McPhillips 2005; Walzer 1998; 2000).

3. Because of space, I have chosen to focus here on the micro-level of structure, and on one story shared by the Synoptics, but it would also be profitable to consider how these concepts apply at the macro-level, and how the Synoptic versions differ from one another. For example, how does Luke's rearrangement of Markan materials shape his Christology (e.g. his geographic schema focused on Jerusalem)? How does Matthew's alternation of Jesus' discourses and actions throughout his Gospel impact Matthean Christology? How do How does Matthew's alternation of Jesus' discourses and actions throughout his Gospel impact Matthean Christology? How do
Matthew's versions of the stories of Jairus' daughter and the haemorrhaging woman in Matthew 9.18-26 differ from those in Mark 5.21-43 and Luke 8.40-56? 
depictions of Jesus are hardly new, and of course Christology as a theological or dogmatic category has been explored for centuries. What, then, distinguishes narrative Christology as its own realm of inquiry? Prior to the development of narrative Christology, modern scholars typically took one of two major approaches to understanding the person of Christ: the so-called titular approach (i.e. a focus on the titles Luke uses for Jesus) or the functional approach (i.e. a focus on Jesus' words and deeds). Narrative Christology complicated and moved beyond these traditional approaches by attempting to understand the person of Jesus through special attention to the narratives we have about him.

Until now, this special attention has tended to coalesce around one of the following three foci: (1) the nature of narrative and its unique capacity to communicate theological truths; (2) literary characterisation as a set of strategies for portraying Jesus as a literary figure (Some of the discussion of literary characterisation in this article reflects claims I develop more fully in Dinkler 2017); and (3) the implications of narrative sequence for readerly meaning-making vis-à-vis Jesus. Let me illustrate each with examples from the secondary literature and from the primary texts of the Synoptic Gospels themselves.

The first kind of narrative Christology emphasises how and why the narrative form is particularly well suited to expressing theological messages. This concerns the nature of narrative itself. Narrative is not just the aesthetic packaging of rational discourse, but a unique form of knowing in and of itself (dubbed by Walter Fisher the 'Narrative Paradigm'; Fisher 1978). As such, narrative not only reflects, but also structures and interprets, the data of human experience. Accordingly, Wendy Doniger (1998) insists:

Narrative does not receive raw experience and then impose a form upon it ... Human experience is inherently narrative; this is our primary way of organizing and giving coherence to our lives. (p. 56)

David Ford's pithy summary applies: 'A realistic narrative is both a "finding" and a "fashioning"' (Ford 1989:196).

Furthermore, if narrative is a form of knowing, and if form itself communicates, then theological truths should not be extracted from their narrative forms and repackaged as theological tenets: 'Far from falling under some thesis detachable from its illustration, therefore, the narrative structure renders any such detachment an act of violence' (Sternberg 1985:33). Bringing these insights to bear on the Gospels, Jerry Camery-Hoggatt (1992) rightly observes:

$[T]$ he relationship between the narrative world of the gospels and the 'historical' life of Jesus is infinitely complicated by factors inherent in narrativity itself, and it cannot have been otherwise. It is precisely because the gospels stand at a critical remove from brute experience that the significance of Jesus can be elaborated here. (p. 39, [italics original])

One of the most obvious counter-examples is, of course, nonnarrative early Christian accounts about Jesus. ${ }^{4}$ In saying

4.I do not mean to imply an absolute dichotomy between narrative and sayings sources (nor do I posit that there were distinct early Christian communities 'behind' them). See the important discussion in the work of Hultgren (2002). this, I am not opposing the claims of scholars like Udo Schnelle or Jens Schröter, who rightly insist that sayings sources like the Gospel of Thomas presuppose a narrative framework, and thus can be seen as having a Christology (Schnelle 2009:388; Schröter 1999; 2001). Rather, my point is that narrative significance cannot be expressed in nonnarrative terms without inherently changing into a different kind of claim.

Unlike other forms of communication (such as rational discursive argument), narrative allows for a high degree of tension, irony and paradox. For example, Dennis Hamm argues that in the Samaritan Leper story (Lk 17:11-19), the Samaritan - a religious outsider - ironically sees what the religious insiders - the Pharisees - cannot see (i.e. the reality of the Kingdom of God in the person and actions of Jesus). Based on the presupposition that narrative uniquely expresses theological truth, Hamm concludes that this pericope stands as its own narrative Christology in miniature (Hamm 1994). Michael Root makes the same assumption when he argues that the Christian gospel would make no sense in any form other than narrative because only narrative can express the 'irreducible complexity' of Christ's stunning defeat or victory on the cross (Root 1984:161).

George Aichele also emphasises that narrative allows for a greater degree of paradox and enigma than non-narrative discourse, but he adds the important nuance that not all narratives do so equally. Looking at the structures of the Synoptics comparatively, Aichele contends that Mark's Gospel, which structurally lacks a proper beginning and end, also has the most mysterious understanding of Jesus; Mark's Jesus is, paradoxically, the triumphant Messiah and the suffering servant, the utmost authority and the slave of all (on which see Davies 1989 and, more recently, Sweat 2015). In contrast, the Gospels of Matthew and Luke both add infancy narratives and endings to their Markan source, and consequently, both portray Jesus with less ambiguity: 'The demand for narrative followability', Aichele avers, 'increasingly overcomes parabolic paradox' (Aichele 1989:54-55). In sum, narrative Christology of this sort concentrates on the ways in which narrative form is especially conducive for expressing complicated theological messages, not least regarding the figure of Jesus.

The second prominent line of interpretation in the realm of narrative Christology concerns the Gospels' depictions of Jesus as a literary figure. Literary characterisation is an enormous area of study in and of itself, in both literary studies and biblical studies; it touches, for example, on questions of identity, narrational strategies and the narrative functions of characters within an unfolding plot - all of which are significant for narrative Christology. ${ }^{6}$ As noted above,

5.Root appeals to Robert Alter (1981), who makes a similar argument with respect to the two creation accounts in Genesis 1 and 2: '[T] he Genesis author chose to the two creation accounts in Genesis 1 and 2: [The Genesis author chose to combine these two versions of creation precisely because he understood that his subject was essentially contradictory, essentially resistant to consistent linear formulation, and that this was his way of giving it the most adequate literary
expression' (p. 145).

The following were published just in the past few years: (Bennema 2014a; 2014b Campbell 2013; Dicken 2014; Dicken \& Snyder 2016; Hunt, Tolmie \& Zimmermann 2013; Skinner 2013; Skinner \& Hauge 2015). 
previous approaches to Christology sought to identify Jesus in terms of his ontology, or essence, apart from the narratives in which he is depicted. Yet, as Hans Frei famously argues in The Identity of Jesus Christ, titles and abstract role descriptions are hardly constitutive of personhood (Frei 1997).

In narrative as in life, identity construction is better understood in terms of an individual's actions and intentions as embodied in and through interactions with others. Tannehill's (1979) point about Mark's Jesus applies to the other Synoptics, as well:

Jesus assumes certain roles in relation to other persons in the narrative, and our understanding of Mark's narrative Christology will be advanced by considering these role relationships. (p. 63)

This is true of all narratives; literary figures are always being characterised in various ways vis-à-vis one another, both explicitly and implicitly. In narrative Christology, Jesus' Christological status is determined by his place in a mutually illuminating dialectic: 'Intermediate characters help the reader to construct the many images projected upon Jesus', and concomitantly, those characters 'are evaluated in light of their responses to him' (Darr 1992:41, 42).

The well-known 'Messianic secret' provides an illustrative example of narrative Christology's shift towards characterisation. In all of the Synoptics, but most commonly in Mark, Jesus refuses to claim Messianic status, silencing those who identify him as such. More traditional approaches explain this motif as evidence of Mark's 'low Christology' (as opposed to the 'high Christology' found elsewhere in the New Testament (NT), where 'low Christology' represents an emphasis on what Jesus does, and 'high Christology' a focus on who Jesus is). Narrative Christology, in contrast, asks about how Jesus speaks and acts in the narrative in relation to other characters, and what such narrative elements can tell us about Markan Christology.

Elizabeth Struthers Malbon's five separate categories of Christological characterisation provide a useful way of laying out textual examples from the Synoptic Gospels (Malbon 1999a; 1999b; 2003; 2004):

1. Enacted Christology (what Jesus does): In the Synoptic Gospels, Jesus' embodied actions include teaching with authority, making predictions that come to pass, exorcising demons and restoring sight to the blind, forgiving sins and suffering and dying on the cross, inter alia. All of this work on earth contributes to our understanding of Jesus' identity as the Christ.

2. Projected Christology (what the narrator and other characters say about Jesus): In Matthew, Mark and Luke, the reliable narrator and other voices of authority present positive portrayals of Jesus, while less reliable characters label him a deviant (see also Gowler 1993:esp. 214). For instance, all three Synoptic narrators refer to Jesus with

7.Anthony Thiselton makes a compelling argument about the latter based on the speech-act theory of J.L. Austin and John Searle: (Austin 1975; Searle 1969; 1979; Thiselton 1994). The literature relating speech-act theory to biblical interpretation is substantial (see, e.g. Briggs 2001). honorific titles like Christ or Messiah, Son of God, Son of Man, Son of David, King of Jews (though with distinct narrative nuances), while the Pharisees say his power comes from the 'prince of demons' (Mk 3:22; Mt 12:24; Lk 11:15). We understand his Christology in part by assessing the statements of others.

3. Deflected Christology (what Jesus says and does in response to others): Jesus' responses vary depending on the circumstance. While he is consistently combative towards those who oppose him, his responses to those who come to him for healing can seem unpredictable. At times, he seems eager to grant a supplicant's request (e.g. Mt 8.3), while elsewhere, he seems reticent (e.g. Mk 7:27). In each case, Jesus' responses to others contribute to the narrative's construction of his identity as the Christ.

4. Refracted Christology (what Jesus says about himself and God): Throughout the triple tradition, Jesus is shown interpreting himself and teaching about God. Luke's Gospel provides an especially clear example of Jesus' selfinterpretation when, after his resurrection, he meets two disciples on the road to Emmaus and explains everything that is said about him in the Scriptures (Lk 24:27).

5. Reflected Christology (how other characters' actions reflect what Jesus says and does): Other characters' actions in response to Jesus call attention to his Christological identity in a variety of ways. For example, Terence Donaldson distinguishes between Matthew's Gospel, which says explicitly that people 'worship' Jesus (e.g. 2:11; 14:33; 28:9, 17), and Mark's Gospel, which portrays a similar idea, but implicitly through descriptions of people falling at Jesus' feet (e.g. 5:22, 33; 7:25; Donaldson 2005).

One need not necessarily adopt Malbon's framework to recognise that any understanding of Jesus as a literary character ought to take into account what John Darr describes as the 'web of interrelationships' established by each Gospel narrative (Darr 1992:41).

A third major strand of narrative Christology underscores the role of narrative sequence in shaping readerly meaningmaking. This can also take a number of different forms. Mark Coleridge (1993) describes his approach to narrative Christology as:

... attending less to the OT background (behind the text) and the retrojection of later New Testament Christology (in front of the text) and more to how the narrator shapes a Christology in the act of narration (within the text). (p. 23)

According to Coleridge, one of the ways in which 'the narrator shapes a Christology in the act of narration' is the strategic use of narrative sequence; Coleridge's monograph, The Birth of the Lukan Narrative: Narrative as Christology in Luke, specifically explores the programmatic impact of the first two chapters of Luke on the rest of the narrative.

Kavin Rowe, on the other hand, traces the use of a particular


Christology, Rowe advances the previous scholarly preoccupation with Luke's titular use of 'Lord' by asking 
how 'the Gospel narrative determines the meaning and significance of the word [kúptoc]' (Rowe 2006:23). Rowe's conclusions are based in part on his view of Luke's sequential narrative development. He argues that Luke consistently portrays Jesus as Lord ( $\kappa$ ṕpıs) throughout the Gospel narrative (as opposed to Hans Conzelmann, for example, who saw in Luke a changing Jesus who begins as a powerful Messiah in Galilee, but ends a suffering servant in Jerusalem).

Let me offer a textual example of how sequence can impact the Synoptic Gospels' narrative depictions of Jesus. All three of the Synoptic Gospels recount the episode in which Peter confesses that Jesus is 'the Christ' (Mt 16:16; Mk 8.29; Lk 9:20). Following this assertion, Jesus teaches his disciples that the Christ must suffer and die, and in Matthew and Mark, Peter promptly responds by taking Jesus aside to rebuke him (Mt 16:22; Mk 8:32). Luke, however, omits any negative exchange between Jesus and Peter, moving directly into the spectacular scene of the Transfiguration. The effect of this sequential narration is that Peter's confession that Jesus is 'the Christ' stands unchallenged, and the Transfiguration, immediately following, serves as a powerful corroboration of that claim.

There are, of course, overlaps between the three iterations of narrative Christology enumerated above. Rowe's (2006) interest in the Lukan use of кúpios, for instance, is thoroughly theological at core; he argues that Luke seeks to:

... tell the human or earthly story of the heavenly Lord. Luke uses kúplos, in other words, to unify the earthly and resurrected Jesus at the point of his identity as Lord. (p. 27)

This is entirely appropriate within the bounds of narrative Christology. While it is important to recognise that there is nothing distinctive about characterisation as a literary phenomenon in the canonical Gospels as opposed to noncanonical narratives, ${ }^{8}$ narrative Christology is an inherently theological category and consequently refuses to bracket the fact that the canonical Gospels are 'shot through with evaluations and theological positions' (Ford 1989:198). We shall return to this consideration below.

Narrative Christology has advanced our understanding of the Gospels' presentations of Jesus through its appreciation of narrative as a unique communicative genre, the Gospels' characterisation strategies and the importance of narrative sequence. Still, I contend that narrative Christology has yet to do real justice to the Gospels' narrative form. I would argue that this is, in part, because of poststructuralist discourses that have engendered in academics a general sense that structuralism is outdated and unhelpful. We can see this, for example, in the fact that studies labelled 'narrative Christology' often fail even to define narrative. The

8.Characterisation is instantiated and functions similarly across ancient narratives (canonical or otherwise); many scholars - particularly classicists - are doing importan comparative work that challenges NT scholars' tendency to privilege this one texts as exceptional literaily. I can only directly would take us too far afield here. Some consider specific genres or corpora, while others treat the same figure across multiple ancient texts. On the former, see,
e.g., ed. Temmerman (2014), Pitcher (2007), Thompson (2001) and ed. Pelling (1990). On the latter, see Damgaard (2016), Wiarda (2000), and Bond (1998). constitutive features of narrativity are debated among narratologists, but most would agree that a narrative must have characters, emplotment, sequential (though not necessarily chronological) narration, causal connections and a teleology or communicative goal. ${ }^{9}$ Judging by Tannehill's call to 'tak[e] seriously the narrative form ... in discussing th $[e]$ Gospel's presentation of Jesus Christ' (Tannehill 1979:57), it would behove us to attend more closely to the constitutive formal features of narrative. Our disciplinary failure to attend closely to literary form and structure limits us unnecessarily. Instead, we ought to grapple with poststructuralism's challenges and nuance our approaches accordingly. The following section introduces literary theory's so-called 'New Formalism', which I believe offers useful ways to do so.

\section{Literary theory's 'New formalism'}

Scholars today tend to consider literary Formalism (e.g. Russian Formalism and New Criticism) outdated. In fact, Richard Strier says Formalism has become a 'dirty word' in literary theory (Strier 2002). However, Formalist theory recently has been revived under the moniker 'New Formalism'. Heather Dubrow first used the phrase 'New Formalism' in 1989 as a corrective to what she saw as an uncritically radical turn towards cultural studies at the expense of form and literary aesthetics. ${ }^{10}$ Although Dubrow and others kept advancing this argument over the following decade and a half (e.g. Kaufman 2000; Strier 2002; Wolfson 1997), the movement truly gained traction following Marjorie Levinson's programmatic 2007 essay, 'What Is New Formalism?'(Levinson 2007). There, Levinson identifies two strains of New Formalism, defining each by its posture towards history: an activist strain, which aims to recover 'an historically informed formalist criticism' (Breslin 1984:xiv; Hunter 2000; Rooney 2000), and a normative strain, which considers form the purview of art alone, not history (e.g. Bérubé 2000; Harpham 2006). Levinson summarises: 'In short, we have a new formalism that makes a continuum with new historicism and a backlash new formalism' (Levinson 2007:559, drawing on Wolfson 2000). Levinson's repeated insistence that New Formalism was, in 2007, a 'movement rather than a theory or a method' prompted subsequent attempts to theorise along New Formalist lines (e.g. eds. Thiele \& Tredennick 2013).

One key theoretical development was New Formalism's rejection of the earlier Formalist view that critics must offer objective value judgements about a text. Verena Thiele writes that instead, New Formalism 'suggests that a text's formal features, its aesthetics, in close conjunction with cultural context, convey a politically and historically significant literary experience that is both intentional and affective' (eds. Thiele \& Tredennick 2013:16). The New Formalist critique of 'old' Formalism was that its conception of proper scholarly

9.Individual narratologists add various other elements. Monika Fludernik, for instance argues that narrativity is dependent on some degree of experientiality evoked for the reader (Fludernik 2010:50). The Gospel narratives clearly mean to evoke experientiality in a way that contemporary academic historiography does not.

10.Douglas Bruster traces Dubrow's first use to a 1989 MLA session titled, 'Toward the New Formalism: Formalist Approaches to Renaissance New Historicism and Feminism' (Bruster 2002). 
criticism problematically required the effacement of an embodied, situated interpreting self. Pushing the critique still further, New Formalists argued that this apparent sense of disembodied interpretation functions rhetorically to conceal and more importantly, to legitimate - scholars' ideological positions by capitalising on 'restrictive ideas of form's givenness (whether as container, or adornment, or genre, or verse-form, or speech act)' (Bogel 2013:85).

Like the variegated Formalisms of the early 20th century, New Formalism cannot be reduced to one perspective, although New Formalists do share certain distinctive aims. Levinson's two strands of New Formalism both aim (albeit in different ways) to recover earlier Formalists' valuing of form, structure and literariness, and to address critiques of Formalism's earlier iterations. Whereas normative Formalists see a new need for 'the defense of the literary' (Rooney 2000:25), Annette Federico typifies activist Formalists as 'seek[ing] a compromise between the New Critical bent toward non-historical and aesthetic reading and the important work of historicists, Marxists, and feminists from the 1980s and after' (Federico 2016:19). Theile summarises: New Formalists offer a 'myriad of answers and kaleidoscopically fragmented visions of how to hone form (back) into a viable theoretical shape and to (re)assign it a critically interventive power' (eds. Thiele \& Tredennick 2013). Nevertheless, they are predicated upon:

a common supposition, namely that literary theory is changing, that New Criticism is not nefarious, that Russian formalism has never been disreputable, that post-structuralism, despite its prefix, does not mark the end of structure, and that New Historicism is not the catch-all that it has been frequently made out to be. (p. 16)

The New Formalist reading I shall advance in the following section shares these views. It is worth remembering, though, that this represents just one of the 'myriad of answers' regarding how to 'hone form (back) into a viable theoretical shape'.

\section{Case study: Jairus' daughter and the haemorrhaging woman (Mk 5:21- 43; Lk 8:40-56; and Mt 9:18-26)}

Our case study is a set of two miracle stories that appear in all three Synoptic Gospels: the twinned stories of Jairus' daughter and the haemorrhaging woman (Mk 5:21-43; Lk 8:40-56; and Mt 9:18-26). These Synoptic parallels clearly reflect the use of the same source materials. The fundamental plot structure is the same in each version: the precipitating event is that a ruler comes to Jesus in search of help for his daughter, who is dead (Matthean version) or dying (Markan and Lukan versions). Suddenly, the narrative is interrupted by a woman who comes up behind Jesus as he is teaching. The woman has been bleeding for 12 years, and she seeks healing. In all three versions, the woman touches Jesus' garment and is miraculously healed of her infirmity; in all three versions, Jesus - Christ the Healer - commends the woman for her faith. The narrative then returns to the ruler's predicament. When Jesus eventually arrives at the ruler's home, he is mocked by the mourners outside, but ultimately heals the girl, raising her up from her deathbed.

The following New Formalism-inflected discussion of these Synoptic healing stories touches on all of the emphases of narrative Christology described above, but most closely aligns with the third - i.e. a concern with the effects of narrative sequence for readerly meaning-making. At the same time, it expands our analysis to consider narrative structure in the light of New Formalist views. New Formalism's distinctive contributions will be clearer by contrast if we begin by considering how these stories have been read traditionally in modern scholarship.

Many critics have sought to contextualise these stories in their historical Sitz im Leben. For example, a common trend among historical-critical scholars has been to diagnose the woman's medical condition. Ironically, however, in their efforts to illuminate the history 'behind' the narrative, scholars have diagnosed her in modern medical terms. For example, in 1903, Wilhelm Ebstein (1903:97) diagnosed her as haemorrhaging from the womb, while nearly 100 years later, J. Keir Howard (2001:94) asserted that her 'dysfunctional uterine bleeding' was 'psychologically generated'.

Still, other historically minded critics have explored the story from an economic perspective; Jerome Neyrey, for example, raises the possibility that the woman takes something of Jesus' without remuneration and therefore, her act is illicit: ' $I]$ f someone secretly obtained healing or some other benefit without the healer's knowledge and remuneration, this might be considered a form of theft' (Neyrey 1999:22). In several senses, then, as James Resseguie states succinctly: 'Her gain is his loss' (Resseguie 2005:139).

Physical, individual and social boundaries have also figured prominently in NT scholars' interpretations of these pericopes. Most commonly, 20th-century scholars appealed to boundaries between 'clean' and 'unclean', or 'pure' versus 'impure'. Bruce Malina (2001) describes the ancient category of 'the unclean' in terms of personal porosity, or bodily boundary-transgression:

[The unclean] include persons suffering from skin disorders or unusual, abnormal bodily flows such as menstruation, seminal emission, suppuration. In these instances the personal boundaries of the individual prove to be porous; the individual is not whole. (pp. 179-180)

This category is, for many interpreters, the pivotal link between these two stories (even, for some, extending into a wider literary context). William Lane, in his 1974 commentary on Mark, expresses the typical view:

A detail which may have contributed to the association of $\mathrm{Ch}$. 5:21-42 with Ch. 5:1-20 is Jesus' contact with the unclean, since the man of the tombs (who is probably a Gentile), the flow of blood and the presence of death all involve Jesus in ceremonial uncleanness. (p. 190 n.35) 
A sociological perspective focuses on the social boundaries instantiated by purity or impurity concepts, and the ritual guidelines for inclusion or exclusion that accompany and sustain them. As Mary Douglas (2002) famously argued:

The only way in which pollution ideas make sense is in reference to a total structure of thought whose keystone, boundaries, margins and internal lines are held in relation by rituals of separation. (p. 51)

If physical imperfections or ailments were viewed as visible manifestations of invisible impurity, then, 'As undesirables, the physically and mentally imperfect functioned materially and symbolically as metaphors or paradigms for religious and social transgressions' (Vlahogiannis 1998:28).

According to this reading, porous bodily boundaries like the haemorrhaging woman's, are dangerous because they threaten the transgression or even dissolution of appropriate social boundaries. If 'the physical body and the corporate social body were thought to mirror each other', then an imperfect physical body 'had the potential of defiling the social body' (Parsons 2011:135). The threat of contamination means, these scholars conclude, that the haemorrhaging woman should have been in a state of social and religious exclusion or quarantine. Joel Marcus, for one, contends that the 'surreptitiousness of the woman's approach to Jesus' should be taken as 'an indirect indication that she is ritually unclean and is violating a taboo by being out in public' (Marcus 2000:357).

To what extent are Jewish ritual purity laws in view (e.g. Theissen 1983:134)? This question has engendered a lively debate: on one side stand those who read through the lens of the Levitical purity laws regarding menstruation. ${ }^{11}$ These scholars note that the two other times in the Bible that the


together are in Leviticus 15:25 and 20:18:

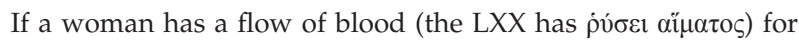
many days, not at the time of her impurity, or if she has a discharge beyond the time of her impurity, all the days of the discharge she shall continue in uncleanness; as in the days of her impurity, she shall be unclean. (15:25)

If a man lies with a woman having her sickness and uncovers her nakedness, he has laid bare her flow and she has laid bare her


them shall be cut off from their people. $(20: 18)$

According to this reading, the Levitical stipulations situate the haemorrhaging woman in a state of perpetual impurity (see also Lv 12:2, 15:19, 20:18; Ezk 36:17). As such, the woman becomes the personification of boundary transgression and deserves to be rebuked, or at least shunned, for appearing in public and touching Jesus.

Jesus, because he does not condemn her, represents a countercultural departure from first-century thinking in this regard.

11.For a brief survey of the major Greek writers' terms for menstruation, see Selvidge (1984).
Selvidge, for instance, concludes that Jesus 'subtly shatters the legal purity system and its restrictive social conditioning' (Selvidge 1984:622). Not only this, but Jesus draws the woman out of the crowd, inviting public attention (especially in the Lukan version $)^{12}$ in a world where, according to Malina, 'to honor a person is to acknowledge publicly that his or her actions conform with social oughts' (Malina 2001:31). In this reading, the Christ becomes an inclusive rebel, erasing the dominant value distinctions of his day and restructuring Jewish insider or outsider schemas.

On the other side of this interpretive debate, however, stand those who aver that Levitical purity laws are irrelevant to this story, and that race and anti-Jewish views are inextricably bound up in the above scholarly assessments (see, e.g. Kelley 2002). Shaye Cohen (1991), for example, noting that Jewish law distinguished between a normal menstruant (nidda) and a woman who bled outside the time of her normal menstrual cycle (zaba), concludes:

The Gospel story about the woman with a twelve-year discharge, clearly a case of $z a b a$, does not give any indication that the woman was impure or suffered any degree of isolation as a result of her affliction. (p. 275) ${ }^{13}$

These interpreters also argue that by the first century CE, purity laws would have been less paramount the further away one lived from the Jerusalem Temple, and note that the Gospel texts avoid the most common terms for menstruation in antiquity (see especially Cohen 1991; Fonrobert 1997, 2000; Levine 1996). Some have objected to purity-related interpretations of these stories as misogynistic (e.g. Dube 2001; Kinukawa 1994). Cohen also points out that although 'the later exclusions of women from contact with the sacred derive, at least nominally, from these biblical laws', still, 'there is no evidence that the intent or immediate effect of these laws was to discriminate against women' (Cohen 1991:276); men, too, were instructed about bodily discharge (see, among others, Lv 15:2-15, 32-33; 22:4; Nm 5:2). In this case, the Christ is a miraculous healer whose earthly ministry - indeed, his incarnation - is characterised by the use of his own body to heal others.

The literary form, or structure, of these stories entered modern NT scholarship from a number of different directions, though all reflect 'restrictive ideas of form's givenness (whether as container, or adornment, or genre, or verse-form, or speech act)' (Bogel 2013:85). Form critics like Dibelius and Bultmann, for their part, identified structural similarities between this and other stories of miraculous healings (or, to use Dibelius' term, Novellen), and first-generation NT narrative critics were not so different. Both groups prioritised the structural features of the stories as a means of classification. David Rhoads, for example, adapts Alter's concept of the type-scene (i.e. a story

12.Luke underscores the public nature of Jesus response. in contrast to the Markan text ('The woman] came in fear and trembling and fell down before him, and told text ([The woman] came in fear and trembling and fell down before him, and told him the whole truth' [5:33]), Luke has, '[The woman] came trembling, and falling down before him declared why she had touched him before all the people, and
how she had been healed immediately' $(8: 47)$. 13. Cohen says this 'important point' is 'unappreciated' by Selvidge (1984) and by Witherington (1984:71-75). 
recounted multiple times, with varied details but stable plot elements; Alter 1981:47-52) for NT narratives, labelling the accounts of Jairus and the haemorrhaging woman 'Suppliant with Faith' type-scenes, wherein a faithful person comes to Jesus for healing, either for her or himself or on behalf of a dependent (Rhoads 1992). Along similar lines, Antoinette Clark Wire classifies these pericopes as 'demand stories', in which 'the demanding party from the first takes an active part in the struggle and overcomes' (Wire 1978:102). ${ }^{14}$

Form critics and literary critics alike have also recognised the literary technique of intercalation as significant. ${ }^{15}$ The woman's story is couched within a narrative frame, or what Edwards has called a 'host pericope' (Edwards 1989:201), in such a way as to form a chiasmus. Many NT exegetes have considered narrative sandwiching to be an invitation to consider the outer and inner stories as mutually illuminating aspects of a one interpretive puzzle (e.g. Fowler 1991:145146). Mark's version is paradigmatic:

\section{A1) 5:21-24 - Jairus asks Jesus to help his daughter \\ B) 5:25-34 - Jesus heals the hemorrhaging woman \\ A2) 5:35-43 - Jesus raises Jairus' daughter}

This formal structure has significant narratological effects; in Mark and Luke, the delay caused by healing the woman along the road creates the narrative time necessary for the girl to die before Jesus arrives. In all three versions, bracketing the Jairus narrative increases the dramatic suspense for readers who must wait to discover what will happen to Jairus' daughter, while simultaneously heightening the miraculous nature of Jesus' act of healing when he arrives (e.g. Shepherd 1995). ${ }^{16}$

Plot pacing is not the only effect of the intercalation. The structure also invites comparison between characters through the use of a literary foil: a character, that is, who 'through contrast underscores the distinctive characteristics of another' (Harmon \& Holman 1999:216). NT scholars generally cannot agree about whether the haemorrhaging woman ought to be compared to the dying girl, Jairus or Jesus. Advocates of the dying girl as literary foil point towards semantic parallels between the two stories, such as the repetition of the number $12(\delta \omega \delta \varepsilon \kappa \alpha)$ in narratorial descriptions of the girl and the

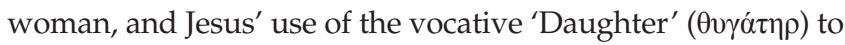
address them both. Additionally, in both accounts, touching Jesus is an important aspect of the healing, and the healing itself happens immediately (Luke twice uses $\pi \alpha \rho \alpha \chi \rho \tilde{\eta} \mu \alpha$, Mark

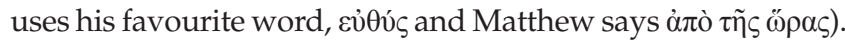

Other scholars draw parallels between Jairus and the woman: both come to Jesus with faith in his ability to heal, and both

14.Examples of other 'demand stories' in the Synoptic Gospels include the accounts of the leper (Mk 1:40-45); the father of the boy with the demon (Lk 9:38-42); the ten lepers (Lk 17:11-19); the Canaanite woman (Mt 15:21-28); and the centurion (Mt 8:5-13).

15.The usual assumption is that intercalations such as this one originated with Mark and are the direct result of his editorial hand (see, e.g., Koch 1975:139; Schenke 1974:198; Von Dobschütz 1928; cf. Twelftree 1999:73).

16.Cf. Matthew, where the girl is already dead before Jairus approaches Jesus. believe in the efficacy of his physical presence; the woman desires to touch him, while Jairus asks him to come physically to his home to heal his daughter. In the Markan and Lukan versions, both express their desperation by falling down $(\pi i \pi \tau \omega)$ at Jesus' feet. Both are contrasted with the unbelieving surrounding crowds, and both are rewarded for their faith with the experience of a miracle. ${ }^{17}$ For these scholars, 'the true foil for the woman is not the little girl, but her father Jairus' (Camery-Hoggatt 1992:138).

Still, others compare the woman to Jesus, especially with respect to their various forms of power. ${ }^{18}$ In the outer narrative, Jesus is the active agent of healing power, intentionally touching the girl to heal her. In the inner story, however, the woman is the active agent, which in Mark and Luke is underscored by the fact that she is healed without the permission - without even the knowledge - of Jesus himself (e.g. Powell 2005). None of the Synoptic parallels stipulates whether the woman's action actually drains Jesus' power. Nor are we told whether Jesus' power is somehow visible (comparable, for example, to the Greek physician Eudemus' purported list of observable bodily leakage: 'vomiting, gastric evacuations, urination, sweats, hemorrhage and normal bleeding piles'; Galen 1979:3.15; 618K). Nevertheless, the fact that Jesus perceives power going out from him in Mark and Luke implies that there is a finite amount from which Jesus senses depletion. Mary Rose D'Angelo argues that the Markan version of this story stresses 'the importance of transfer of power and of touch as its means in striking ways' (D'Angelo 1999:98). ${ }^{19}$ In Mark and Luke, 'Jesus' parting commendation of her faith simply concedes to her what she has already taken from him: the power with which to supply her weakness' (D'Angelo 1999:99). The question, though, remains: Which is it? Is the most productive comparison between the woman and Jesus, Jairus or the girl?

Two developments in New Formalism offer helpful perspectives from which to answer this question. Firstly, many New Formalists embrace multiple possible readings where their predecessors would not. Daniel Schwarz, for instance, lauding New Formalism, advocates a 'pluralistic approach, which allows for multiple perspectives' (Schwarz 2008:xiii). Thus, a New Formalist might suggest that there is no reason to choose. All three characters - the dying girl, Jairus and Jesus - function as foils to the haemorrhaging woman, and vice-versa. For the New Formalist, it is more important to recognise the rhetorical effects of juxtaposing the characters to one another within each Gospel's 'web of interrelationships' than it is to determine which one character is a definitively 'better' foil for another (Darr 1992:41).

17.On the possibility that the woman's faith is in Jesus as a magician, see Edwards (1989:204) and Witherington (1984:73).

18.Moss (2010:516) calls this 'the obvious comparison'.

19.Notably, this transfer of power does not require human contact; even contact with a holy person's garment can engender miraculous healing (Mk 6:56; cf. Mt 9:20; 14:36; Lk 8:44; Ac 19:11-12). This may reflect the view that one's garments are somehow connected to the self (cf. Plutarch's Life of Sulla, 35:4). Resseguie argues somenow connected to the self (cf. Plutarch's Life of Sulla, 35:4). Resseguie argues
that Jesus' 'clothing is identical to his selfhood', though for a different reason (Resseguie 2005:139). 
Secondly, viewing form and content as embedded in particular social and historical contexts, New Formalists appreciate references to external background information where a strictly New Critical or 'old' Formalist approach would not. Federico poses the relevant question: 'Is there a way to combine a wish to delve into the aesthetic complexity of a literary work with a concern for its life in politics and history?' (Federico 2016:19). Considering these Synoptic stories' 'life in [the] politics and history' of ancient contexts illuminates the multilayered social reversals at work. As many NT scholars have observed, the interactions between the main characters - that is, interactions between Jairus and Jesus, the woman and Jairus, and Jesus and the woman challenge ancient norms on a number of levels.

Take, for instance, the contrasts between Jairus and the woman. Jairus, as a healthy male, a father and a synagogue

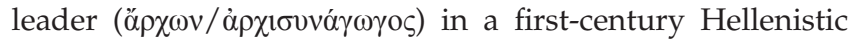
Jewish world, likely would have occupied a venerated social position; standing at the centre of his community or communities, he represents the values of those in power. It is appropriate, then, that he approaches Jesus face-to-face. Situated in this first-century Sitz im Leben, the haemorrhaging woman, on the other hand, is marginal: she is unnamed, ${ }^{20}$ chronically ill and presumably poor; in Mark, at least, she has spent 'all' ( $\pi \alpha \dot{v} v \alpha)$ that she had on physicians. Mark and Luke further highlight the abnormality of her condition by mentioning that she is incurable (Mk 5:26; Lk 8:43). ${ }^{21}$ It is unsurprising that unlike Jairus, she approaches Jesus from behind (ö $\pi \sigma \theta \varepsilon v)$. Yet, these respective positions change as events unfold. As Joel Marcus and others have observed, 'their fortunes seem to be suddenly reversed' (Marcus 2000:366). The woman begins 'at the opposite end of the social, economic, and religious spectrum from Jairus', but in the end, 'his loss of time becomes her gain' (Marcus 2000:366).

New Formalism invites us to ask how these social and cultural dynamics function in conjunction with the narrative's formal features. The inversions of power relationships discussed above occur within the storyworld. Yet, the structural elements of these intercalated stories also contribute to our construction of meaning. For example, Moss, discussing the flow of power between Jesus and the woman, remarks that 'the mechanics of the healing' entail a 'reversal of fortunes for the physician and patient' (Moss 2010:516). I would add to this the observation that the mechanics of form organise, enact - and even in some ways threaten to undo - such reversals. Let me unpack this claim.

Consider again the chiasmus created by the two stories. Drawing on cognitive stylistics to bridge the gap between the 'activist' and 'normative' strands of New Formalism, Karin Kukkonen insists that 'form organizes content and provides

20.The difference between Jairus and the woman is even more pronounced in the Markan and Lukan versions than in the Matthean version, because Jairus is named in Mark and Luke, but remains unnamed in Matthew. On the significance of proper names (see Bauckham 2002; Beck 1997; Reinhartz 1998).

21.Several early manuscripts reflect a Lukan change here. Whereas Mark tells his readers that the woman spent all her money on doctors, Luke (traditionally, but not likely, the 'Beloved Physician') simply says that no one could help her. a pattern of thinking' (Kukkonen 2013:166). Consequently, a chiasmus functions not only as a 'repetition that reverses grammatical structures', but also as 'an inversion of the power relationship between participants ... The chiasmus inverts relationships between content' (Kukkonen 2013:166). Patrick O'Neill (1994) makes a similar observation when he writes:

$[T]$ he relationship between nested narratives is always one of mutual relativization, while the embedding narrative is ultimately always in a position to colour fundamentally our reception of an embedded narrative, it may itself always in turn be challenged or even displaced altogether by the narrative it embeds. (p. 65)

While Jairus pleads with Jesus to heal his daughter, the woman - with her excessive blood flow - interrupts the narrative flow. The reader's perception of the interruption is focalised through the woman, who is described not only as having bled for 12 years, but (in Mark) as having 'suffered much' ( $\pi \mathrm{o} \lambda \lambda \grave{\alpha} \pi \alpha \theta \mathrm{ov} \sigma \alpha, 5.26$ ), and (in Luke) as

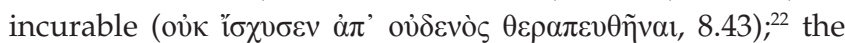
narration, that is, foregrounds the woman's experience (narratologists discuss this aspect of narration in terms of focalisation, which is similar to the concept of point of view).

The narrator's control of knowledge and perspective guides readers in their interpretive judgements of this scene. The reader unlike the other characters in the story - sees the woman in the crowd, the reader is told the reason for her presence, and the reader watches her come up behind Jesus and touch his garment. Because readers have more knowledge than certain actants in the story, it can be difficult for them to remain neutral outside observers. Narrative development turns on the discrepancies in knowledge between the characters and the reader. The readers' understanding of the story is aligned with the woman's perspective, in contrast to the disciples' and Jesus' perspectives.


and the reader's knowledge of the answer heighten the tension and create dramatic irony. With these reader-elevating strategies of focalisation, the narrator effectively creates a cohort of informed insiders; as Paul Duke puts it, 'Irony rewards its followers with a sense of community' (1985:38-39). This situates the reader over and against the disciples, who 'are shown to have little faith in Jesus and little understanding of why Jesus would ask who touched Him in such a mob' (Witherington 1984:73).

From a New Formalist perspective, what is remarkable about these intercalated tales is that 'the chiasmus inverts relationships between content' - that is, Jesus and Jairus are decentred as the central active agents, while the woman takes centre stage as the protagonist at the inner core of a framed narrative (Kukkonen 2013:166). In a world that has marginalised this woman in more ways than one, she is suddenly right in the centre of the action - both literally and figuratively - while Jairus, the respectable Jewish leader who

22.Yamasaki (2012:58) discusses this in terms of narratorial control of information flow. On the functions of knowledge acquisition in biblical narrative, see Sternberg (1985:esp. 153-185). 
embodies the social centre, is relegated to the margins of the narrative.

Moreover, if we accept the Formalist view that form itself communicates, then we can see the interruption as a literary instantiation of an important theological message, one with ramifications for our understanding of the Synoptic narratives' Christology or Christologies: those in the centre are not more deserving of Christ's attention than those on the margins. The Messiah does not prioritise those with power, nor even those whose need seems more urgent. This is especially striking when one considers that in Mark and Luke, Jairus' daughter has not yet died when the woman stops Jesus. The woman has been bleeding for 12 years - the entirety of the young girl's life. Presumably, a few more hours while Jesus attends to the dying girl would not make much of a difference in the woman's condition. The Christ nevertheless stops, and Jairus' plotline is put on hold. Indeed, it is only because Jairus' story stops on the level of the discourse that the woman's blood flow stops on the level of the story. In this regard, what happens on the level of the story occurs simultaneously on the level of the discourse such that form and content mirror and reinforce one another.

And yet New Formalism also points up intricate and contradictory connections between the body of the text (i.e. its form) and the bodies in the text. Heeding Sasha Roberts' call for 'reconciliation between new formalism and feminist criticism', we might turn to the well-known constructions of gendered bodies in antiquity (Roberts 2007). ${ }^{23}$ Ancient Greek physiological formulations distinguish between female bodies as porous and leaky, and male bodies as contained and solid:

In women the nature of glands ... is loose textured $\ldots$ but in males both the compactness and the solidity of their bodies contribute greatly to the glands not becoming big ... the female, on the other hand, is loose textured and spongy. (Gland. 16, L. VIII. 572) ${ }^{24}$

Further, as Cohen rightly points out, 'underlying the Hippocratic characterization of male and female flesh is a value judgment: firm and compact is good/loose and spongy is bad' (Cohen 1991:115). This view continued to hold sway long beyond the time of Hippocrates; Ann Ellis Hanson demonstrates that, 'post-Hippokratic female physiology continue[d] to view woman as a creature of excess' (Hanson 1990:333). In that historical context, then, some scholars have read this Synoptic pericope as an overturning of normative gender expectations. If both the woman and Jesus are 'porous, leaky creatures', then in terms of ancient construals of gender, Jesus' masculinity and indeed, his identity as the Christ - is threatened (Moss 2010:516). In contrast, the woman's healed body becomes more 'bounded', more male and as such more valuable (e.g. Moss 2010:515; Wilson 2015:199).

23.One self-proclaimed 'attempt to answer that call' is Scott-Baumann (2013:9).

24.See also, e.g., Aristotle, Historia Animalium 1.220-223, and the discussion in DeanJones (1989).
A New Formalist interpretive lens allows us to see hierarchical gender disparities operating not only on the level of sentience, but on the level of the sentence - not only on the level of bodily form, but on the level of narrative form. Consider again the fact that Jairus' story 'forms a parenthesis' around the woman's story. This could be read in two contrasting ways: on the one hand, it could be read in feminist terms as an unusual centring of a female character, on the levels of both form and content. As the woman's story is recounted, Jairus and his concerns fade into the background. On this reading, Christ liberates the woman not only from her physical ailment, but also from the larger societal structures that oppress and constrict her (Douglas 2005; Grant 1989). On the other hand, the intercalated form could also effectively render the woman a parenthetical remark - an aside, a departure from the important (male-dominated) storyline (Resseguie 2005:138). After all, Jairus reappears once the woman has been healed, whereas we never see or hear from the woman again. The form, in other words, moves the woman from the margins to the centre, but her story - like her healed body - ultimately remains bounded, contained within the strictures of the outer (male-dominated) frame narrative. In this case, Christ sends the woman back into the world of her oppressors, 'healed', but hardly liberated.

\section{Conclusion}

A New Formalist approach is richly textured and widely contextualised, allowing for capacious (sometimes contradictory) considerations of the formal features of narrative. To reiterate, my resistance to arguing definitively for one or the other of the above readings should not be construed as implicitly advocating interpretive relativism or anarchy. Narrative form limits our interpretive options even as it gives rise to multiple potential meanings. In my view, the more important point is that a narrative Christology informed by New Formalism can help us reshape our own perceived disciplinary boundaries, which have unnecessarily limited our inquiries into the structures of the Gospel narratives.

\section{Acknowledgements Competing interests}

The author declares that she has no financial or personal relationships which may have inappropriately influenced her in writing this article.

\section{References}

Aichele, G., 1989, 'Literary fantasy and the composition of the gospels', Forum 5, 42-60. Alter, R., 1981, The art of biblical narrative, Basic Books, New York.

Austin, J.L., 1975, How to do things with words, 2nd edn., Harvard University Press, Cambridge, MA.

Bauckham, R., 2002, Gospel women: Studies of the named women in the gospels, William B Eerdmans, Grand Rapids, MI.

Beck, D., 1997, The discipleship paradigm: Readers and anonymous characters in the fourth Gospel, Brill, Leiden.

Bennema, C., 2014a, Encountering Jesus: Character studies in the Gospel of John, 2nd edn., Augsburg, Minneapolis, MN.

Bennema, C., 2014b, A theory of character in New Testament narrative, Fortress Press, Minneapolis, MN.

Bérubé, M., 2000, 'Aesthetics and the literal imagination', in D. Richter (ed.), Falling into theory: Conflicting views on reading literature, pp. 391-398, Bedford, Boston, MA. 
Bogel, F.V., 2013, New formalist criticism: Theory and practice, Palgrave Macmillan, New York.

Bond, H., 1998, Pontius Pilate in history and interpretation, Cambridge University Press, Cambridge.

Breslin, J., 1984, From modern to contemporary: American poetry, 1945-1965, University of Chicago Press, Chicago, IL.

Briggs, R., 2001, 'The uses of speech-act theory in biblical interpretation', Currents in Research: Biblical Studies 9, 229-276.

Bruster, D., 2002, 'Shakespeare and the composite text', in M.D. Rasmussen (ed.), Renaissance literature and its formal engagements, pp. 43-66, Palgrave, New York.

Camery-Hoggatt, J., 1992, Irony in Mark's gospel: Text and subtext, Cambridge University Press, Cambridge.

Campbell, K., 2013, Of heroes and villains: The influence of the Psalmic lament on synoptic characterization, Wipf \& Stock Publishers, Eugene, OR.

Cohen, S., 1991, 'Menstruants and the sacred in Judaism and Christianity', in S Pomeroy (ed.), Women's history and ancient history, pp. 273-299, University of North Carolina Press, Chapel Hill, NC.

Coleridge, M., 1993, The birth of the Lukan narrative: Narrative as Christology in Luke 1-2, Journal for the Study of the New Testament: Supplement Series 88, Sheffield Academic, Sheffield.

Damgaard, F., 2016, Rewriting Peter as an intertextual character in the canonical gospels, Routledge, London.

Dinkler, M.B., 2017, 'Building Character on the Road to Emmaus: Lukan Characterization in Contemporary Literary Perspective', Journal of Biblical Literature, 687-706.

D'Angelo, M.R., 1999, 'Gender and power in the Gospel of Mark: The daughter of Jairus and the woman with the flow of blood', in J.C. Cavadini (ed.), Miracles in Jewish and Christian antiquity: Imagining truth, pp. 83-109, University of Notre Dame Press, Notre Dame, IN.

Darr, J.A., 1992, On character building: The reader and the rhetoric of characterization in Luke-Acts, Literary Currents in Biblical Interpretation, Westminster John Knox, Louisville, KY.

Davies, P.G., 1989, 'Mark's christological paradox', Journal for the Study of the New Testament 35, 3-18. https://doi.org/10.1177/0142064X8901103501

Dean-Jones, L., 1989, 'Menstrual bleeding according to the Hippocratics and Aristotle', Transactions of the American Philological Association 119, 177-192. https://doi. org $/ 10.2307 / 284268$

Dicken, F., 2014, Herod as a composite character in Luke-Acts, Mohr Siebeck, Tübingen.

Dicken, F. \& Snyder, J. (eds.), 2016, Character and characterization in Luke-Acts, Bloomsbury/T\&T Clark, London.

Donaldson, T., 2005, 'The vindicated son: A narrative approach to Matthean christology', in R.N. Longenecker (ed.) Contours of Christology in the New Testament, pp. 100-121, William B. Eerdmans, Grand Rapids, MI.

Doniger, W., 1998, The implied spider: Politics and theology in myth, Columbia University Press, New York.

Douglas, K.B., 2005, What's faith got to do with it? Black bodies/Christian souls, Maryknoll Books, New York.

Douglas, M., 2002, Purity and danger: An analysis of the concept of pollution and taboo, Routledge, New York.

Dube, M., 2001, 'Fifty years of bleeding: A storytelling feminist reading of Mark 5:24$43^{\prime}$, in M. Dube (ed.), Other ways of reading: African women and the bible, pp. 50-60, WCC Publications, Geneva.

Duke, P. 1985, Irony in the Fourth Gospel, John Knox Press, Louisville, KY

Ebstein, W., 1903, Die Medizin im Neuen Testament und im Talmud [Medicine in the New Testament and in the Talmud], Enke, Stuttgart.

Edwards, J.R., 1989, 'Markan sandwiches: The significance of interpolations in Markan narratives', Novum Testamentum 31, 193-216.

Federico, A., 2016, Engagements with close reading, Routledge, London.

Fisher, W., 1978, 'Toward a logic of good reasons', Quarterly Journal of Speech 64 376-384. https://doi.org/10.1080/00335637809383443

Fludernik, M., 2010, 'Experience, experientiality, and historical narrative: A view from narratology', in T. Breyer \& D. Creutz (eds.), Erfahrung und Geschichte. Historische Sinnbildung im Pränarrativen [Experience and history: Historical creation of meaning in prenarrative], pp. 40-72, Walter de Gruyter, Berlin.

Fonrobert, C., 1997, 'The woman with a blood-flow (Mark 5:24-34) revisited Menstrual laws and Jewish culture in Christian feminist hermeneutics', in C. Evans $\&$ J. Sanders (eds.), Early Christian interpretation of the scriptures of Israel, pp. 121-140, Sheffield Academic, Sheffield.

Fonrobert, C., 2000, Menstrual purity: Rabbinic and Christian reconstructions of biblical gender, Stanford University Press, Stanford, CA.

Ford, D., 1989, 'System, story, performance: A proposal about the role of narrative in systematic theology', in S. Hauerwas \& L.G. Jones (eds.), Why narrative?: Reading in narrative theology, pp. 191-215, William B. Eerdmans, Grand Rapids, MI.

Fowler, R.M., 1991, Let the reader understand: Reader-response criticism and the Gospel of Mark, Fortress Press, Minneapolis, MN.

Frei, H., 1997, The identity of Jesus Christ: The hermeneutical bases of dogmatic theology, Wipf \& Stock Publishers, Eugene, OR.

Galen, 1979, On prognosis, ed. and transl. V. Nutton, Corpus Medicorum Graecorum 5.8.1 Akademie-Verlag, Berlin.
Gowler, D.B., 1993, 'Hospitality and characterization in Luke 11: 37-54: A socionarratological approach', Semeia 64, 213-251.

Grant, J., 1989, White women's Christ and black woman's Jesus: Feminist Christology and womanist response, Scholars Press, Atlanta, GA.

Hamm, D., 1994, 'What the Samaritan leper sees: The narrative Christology of Luke 17:11-19', Catholic Biblical Quarterly 56, 273-287.

Hanson, A.E., 1990, 'The medical writers' woman', in D.M. Halperin, J.J. Winkler \& F.I. Zeitlin (eds.), Before sexuality: The construction of erotic experience in the ancient Greek world, pp. 308-338, Princeton University Press, Princeton, NJ.

Harmon, W. \& Holman, C.H., 1999, A handbook to literature, 8th edn., Prentice Hall, Upper Saddle River, NJ.

Harpham, G., 2006, The character of criticism, Routledge, London.

Howard, J.K., 2001, Disease and healing in the New Testament: An analysis and interpretation, University Press of America, New York.

Hultgren, S., 2002, Narrative elements in the Double-Tradition: A study of their place in the framework of the gospel narrative, Beihefte zur Zeitschrift für die neutestamentliche Wissenschaft 113, Walter de Gruyter, Berlin.

Hunt, S., Tolmie, D.F. \& Zimmermann, R. (eds.), 2013, Character studies in the fourth Gospel, Mohr Siebeck, Tübingen.

Hunter, J.P., 2000, 'Formalism and history: Binarism and the Anglophone couplet', Modern Language Quarterly 61, 109-129. https://doi.org/10.1215/00267929-611-109

Kaufman, R., 2000, 'Everybody hates Kant: Blakean formalism and the symmetries of Laura Moriarty', Modern Language Quarterly 61, 131-155. https://doi. org/10.1215/00267929-61-1-131

Kelley, S., 2002, Racializing Jesus: Race, ideology and the formation of modern biblical scholarship, Routledge, New York.

Kinukawa, H., 1994, 'The story of the hemorrhaging woman (Mark 5:25-34) read from a Japanese feminist context', Biblical Interpretation 2, 283-293. https://do org/10.1163/156851594X00097

Koch, D.-A., 1975, Die Bedeutung der Wundererzählungen für die Christologie des Markusevangeliums [The meaning of the miracle stories for the Christology of the Gospel of Mark], Walter de Gruyter, New York.

Kukkonen, K., 2013, 'Form as a pattern of thinking: Cognitive poetics and New Formalism', in V. Thiele \& L. Tredennick (eds.), New formalisms and literary theory, pp. 159-178, Palgrave MacMillan, Basingstoke.

Lane, W., 1974, The Gospel of Mark, New International Commentary on the New Testament, William B. Eerdmans, Grand Rapids, MI.

Levine, A.-J., 1996, 'Discharging responsibility: Matthean Jesus, biblical law, and hemorrhaging woman', in D. Bauer \& M. Powell (ed.), Treasures new and old: Contributions to Matthean studies, pp. 379-397, Scholars Press, Atlanta, GA.

Levinson, M., 2007, 'What is new formalism?', Publications of the Modern Language Association of America 122, 558-569. https://doi.org/10.1632/pmla.2007.122. 2.558

Malbon, E.S., 1999a, 'The Christology of Mark's Gospel: Narrative Christology and the Markan Jesus', in M.A. Powell \& D.R. Bauer (eds.), Who do you say that I am Essays on Christology, pp. 33-48, Westminster John Knox, Louisville, KY.

Malbon, E.S., 1999b, "Reflected Christology": An aspect of narrative Christology in the Gospel of Mark', Perspectives in Religious Studies 26, 127-145.

Malbon, E.S., 2003, 'Narrative Christology and the Son of Man: What the Markan Jesus says instead', Biblical Interpretation 11, 373-385. https://doi. org/10.1163/156851503322566796

Malbon, E.S., 2004, 'Markan narrative Christology and the kingdom of God', in S.H. Ringe \& H.C.P. Kim (eds.), Literary encounters with the reign of God, pp. 177-193, T\&T Clark International, New York.

Malina, B., 2001, The New Testament world: Insights from cultural anthropology, 3rd edn., Westminster John Knox, Louisville, KY.

Marcus, J., 2000, Mark 1-8, The Anchor Bible 27, Doubleday, New York.

McPhillips, R., 2005, The New Formalism: A critical introduction, expanded edition, 2nd edn., Textos Books, Cincinnati, $\mathrm{OH}$

Moss, C.R., 2010, 'The man with the flow of power: Porous bodies in Mark 5:25-34', Journal of Biblical Literature 129(3), 507-519. https://doi.org/10.2307/25765949

Neyrey, J., 1999, 'Miracles, in other words: Social science perspectives on healings', in J.C. Cavadini (ed.), Miracles in Jewish and Christian antiquity: Imagining truth, pp. 19-56, University of Notre Dame Press, Notre Dame, IN.

O'Neill, P., 1994, Fictions of discourse: Reading narrative theory, University of Toronto Press, Toronto, ON.

Parsons, M.C., 2011, Body and character in Luke and Acts, Baker Academic, Grand Rapids, MI.

Pelling, C. (ed.), 1990, Characterization and individuality in Greek literature, Clarendon, Oxford.

Pitcher, L., 2007, 'Characterization in ancient historiography', in J. Marincola (ed.) Blackwell companion to Greek and Roman historiography, pp. 102-117, Blackwell, Oxford.

Powell, C., 2005, 'The "passivity" of Jesus in Mark 5: 25-34', Bibliotheca Sacra 162, 66-75.

Reinhartz, A., 1998, Why ask my name? Anonymity and identity in the biblical narrative, Oxford University Press, New York.

Resseguie, J.L., 2005, Narrative criticism of the New Testament: An introduction, Baker Academic, Grand Rapids, MI. 
Rhoads, D., 1992, 'The Syrophoenician woman in Mark: A narrative-critical study' Journal of the American Academy of Religion 62, 342-375.

Roberts, S., 2007, 'Feminist criticism and the New Formalism: Early modern women and literary engagement', in D. Callaghan (ed.), The impact of feminism in English Renaissance studies, pp. 67-91, Palgrave Macmillan, New York.

Rooney, E., 2000, 'Form and contentment', Modern Language Quarterly 61, 17-40. https://doi.org/10.1215/00267929-61-1-17

Root, M., 1984, 'Dying he lives: Biblical image, biblical narrative, and the redemptive Jesus', Semeia 30, 155-169.

Rowe, C.K., 2006, Early narrative Christology: The Lord in the Gospel of Luke, Beihefte zur Zeitschrift für die neutestamentliche Wissenschaft und die Kunde der älteren Kirche 139, Walter de Gruyter, Berlin.

Schenke, L., 1974, Die Wundererzählungen des Markusevangeliums [The miracle stories of the Gospel of Mark], Verlag Katholisches Bibelwerk, Stuttgart.

Schnelle, U., 2009, Theology of the New Testament, transl. E.M. Boring, Baker Academic, Grand Rapids, MI.

Schröter, J., 1999, 'Entscheidung für die Worte Jesu. Die Logienquelle in der Geschichte des frühen Christentums' [Ruling for the words of Jesus: The sayings source in the history of early Christianity], BiKi 54, 70-74.

Schröter, J., 2001, 'Q et la christologie implicite' [Q and implicit Christology], in A. Lindemann (ed.), The Sayings Source $Q$ and the Historical Jesus, pp. 289-316, Leuven University Press, Leuven.

Schwarz, D., 2008, In defense of reading, Blackwell, Malden, MA.

Scott-Baumann, E., 2013, Forms of engagement: Women, poetry and culture 16401680, Oxford University Press, Oxford.

Searle, J.R., 1969, Speech acts: An essay in the philosophy of language, Cambridge University Press, Cambridge.

Searle, J.R., 1979, Expression and meaning: Studies in the theory of speech acts, Cambridge University Press, Cambridge.

Selvidge, M., 1984, 'Mark 5:25-34 and Leviticus 15:19-20', Journal of Biblical Literature 103, 619-623. https://doi.org/10.2307/3260473

Shepherd, T., 1995, 'The narrative function of Markan intercalation', New Testamen Studies 41, 522-540. https://doi.org/10.1017/S0028688500021688

Skinner, C. (ed.), 2013 Characters and characterization in the Gospel of John, Bloomsbury/T\&T Clark, London.

Skinner, C. \& Hauge, M. (eds.), 2015, Character studies and the Gospel of Mark Bloomsbury/T\&T Clark, London.

Sternberg, M., 1985, The poetics of biblical narrative: Ideological literature and the drama of reading, Indiana University Press, Bloomington, IN.

Strier, R., 2002, 'How formalism became a dirty word, and why we can't do without it', in M.D. Rasmussen (ed.), Renaissance literature and its formal engagements, pp. 207-216, Palgrave, New York.
Sweat, L., 2015, The theological role of paradox in the Gospel of Mark, Library of New Testament Studies 492, Bloomsbury/T\&T Clark, London.

Tannehill, R., 1979, 'The Gospel of Mark as narrative Christology', Semeia 16, 57-95.

Temmerman, K.D. (ed.), 2014, Crafting characters: Heroes and heroines in the ancient Greek novel, Oxford University Press, Oxford.

Theissen G., 1983, The miracle stories of the early Christian tradition, transl. F. McDonagh, Fortress Press, Philadelphia, PA.

Thiele, V. \& Tredennick, L. (eds.), 2013, New formalisms and literary theory, Palgrave, Basingstoke.

Thiselton, A., 1994, 'Christology in Luke, speech-act theory, and the problem of dualism in Christology after Kant', in J. Green \& M. Turner (eds.), Jesus of Nazareth: Lord and Christ. Essays on the historical Jesus and New Testament theology, pp. 453-472, William B. Eerdmans, Grand Rapids, MI.

Thompson, R., 2001, 'Reading beyond the text, part II: Literary creativity and characterization in narrative religious texts of the Greco-Roman world', ARC 29, 81-122.

Twelftree, G., 1999, Jesus the miracle worker: A historical and theological study, InterVarsity Press, Downers Grove, IL.

Vlahogiannis, N., 1998, 'Disabling bodies', in D. Montserrat (ed.), Changing bodies, changing meanings: Studies on the human body in antiquity, pp. 13-54, Routledge, London.

Von Dobschütz, E., 1928, 'Zur Erzählerkunst des Markus' [On the narrative art of mark], Zeitschrift für die neutestamentliche Wissenschaft und die Kundeder älteren Kirche 27, 193-198.

Walzer, K., 1998, 'Dana Gioia and expansive poetry', Italian Americana 16, 24-40.

Walzer, K., 2000, The ghost of tradition: Expansive poetry and postmodernism, Story Line Press, Ashland, OR.

Wiarda, T., 2000, Peter in the gospels: Pattern, personality and relationship, Wissenschaftliche Untersuchungen zum Neuen Testament 2/157, Mohr Siebeck, Tübingen.

Wilson, B., 2015, Unmanly men: Refigurations of masculinity in Luke-Acts, Oxford University Press, Oxford.

Wire, A.C., 1978, 'The gospel miracle stories and their tellers', Semeia 11, 83-113.

Witherington, B., 1984, Women in the ministry of Jesus, University of Cambridge Press, Cambridge.

Wolfson, S.J., 1997, Formal charges: The shaping of poetry in British Romanticism Stanford University Press, Stanford, CA.

Wolfson, S.J., 2000, 'Reading for form', Modern Language Quarterly 61, 1-16. https:// doi.org/10.1215/00267929-61-1-1

Yamasaki, G., 2012, Point of view and evaluative guidance in biblical narrative, Cascade Books, Eugene, OR. 